Energy Shortages and the Politics of Time: Resilience, Redistribution and 'Normality' in Japan and East Germany, 1940s-1970s

\title{
Shin, Hiroki
}

Bloomsbury Academic

2019

Shin , H \& Trentmann , F 2019 , Energy Shortages and the Politics of Time: Resilience,

Redistribution and 'Normality' in Japan and East Germany, 1940s-1970s . in FA Jonsson , J Brewer , N Fromer \& F Trentmann (eds), SCARCITY IN THE MODERN WORLD:

HISTORY, POLITICS, SOCIETY AND SUSTAINABILITY, 1800-2075 . Bloomsbury

Academic , New York, NY , pp. 247-265 . https://doi.org/10.5040/9781350040946.ch-015

http://hdl.handle.net/10138/330330

https://doi.org/10.5040/9781350040946.ch-015

unspecified

draft

Downloaded from Helda, University of Helsinki institutional repository.

This is an electronic reprint of the original article.

This reprint may differ from the original in pagination and typographic detail.

Please cite the original version. 


\title{
Energy Shortages and the Politics of Time: Resilience, Redistribution and 'Normality' in Japan and East Germany, 1940s-1970s
}

\author{
Hiroki Shin and Frank Trentmann
}

In contemporary memory, the 1973 oil crisis appears as the watershed between a post-war era of affluence and a new period of pessimism worried about the limits of growth and resources shortages. ${ }^{1}$ Yet energy shortages were a recurrent feature of the twentieth century, as well as in earlier periods. Today, shortages are associated with underdeveloped or developing countries, with sometimes serious consequences to public health. Zanzibar in Tanzania, for example, was without power for a month in the early summer of 2008 and for three months in 2010. The 2008 blackout was accompanied by a reduction in the birth weights of babies with in utero exposure to the blackout. ${ }^{2}$ Nor does economic growth on its own eliminate the severity of cuts; the biggest blackout in history occurred in an emerging economy, India, in late July 2012 and affected 620 million people. ${ }^{3}$

It is easy to forget that the most advanced industrial societies also went through periods where they battled with shortages. Some of these were the result of military conflict, most notably the coal shortages and rationing of the two world wars. But peacetime was equally disrupted by intermittent shortages, the result of strikes (e.g. Germany in 1919-20), austerity (1932), technical failures and natural disasters, and sometimes a combination of these. Europe's cold winter of 1963 and the New York blackout of 1965 were only the most dramatic instances of disruption. ${ }^{4}$ Britain faced severe electricity shortages in 1947-48 and 1963, Japan in 1946-49, 1951-53 and

1 For example, see Dominic Sandbrook's (2010), State of Emergency: The Way We Were: Britain 1970-1974, London and his (2012) Seasons in the Sun: The Battle for Britain, 1974-1979, London. For other perspectives, see Frank Bösch and Rüdiger Graf (eds.), Historical Social Research: Special Issue 'The Energy Crisis of the 1970s', 39 (4) (2014).

2 Alfredo Burlando (2010), 'The Impact of Electricity on Work and Health: Evidence from a Blackout in Zanzibar'. Available at https://www.aeaweb.org/conference/2011/retrieve.php?pdfid=523.

3 Sunila Kale (2014), Electrifying India: Regional Political Economies of Development, pp. 176-178, Stanford, CA; International Energy Agency (2005), Saving Electricity in a Hurry: Dealing with Temporary Shortfalls in Electricity Supplies, Paris. See also the chapters on Lagos, India and China in this volume.

4 David Nye (2010), When the Lights Went Out, Cambridge, MA. 
1956-57, in addition to gas shortages in 1961, 1965 and 1969. Industrial growth and the rapid expansion of private electricity use made developed societies worry about energy security well before OPEC announced its oil embargo in October 1973.

In this chapter, we revisit real and feared energy shortages between the end of the Second World War and the first oil crisis in 1973, focusing on the experience of two societies: Japan and East Germany (GDR). Our aim is, partly, to overcome amnesia and to suggest that shortages were an integral feature of affluence and growth - and not only of recession. But we are equally interested in shortages for what they can reveal about the coping mechanisms of advanced modern societies. Attention to the two oil crises of the 1970s tends to highlight external factors and causes. But most shortages were also shaped by internal social and political dynamics. Instead of focusing on immediate causes, we use shortages to illuminate how societies cope under stress by comparing the priorities and mechanisms at play in a capitalist regime with those in a planned socialist economy.

At the centre of this discussion is the distributional politics of who gets what and when. It also concerns distribution across times of day and seasons. Shortages have distinct temporal features, depending on both the seasons and the daily evening peak of electricity use. Disruption in the flow of resources sets in motion a politics of time that favours some users at the expense of others and some practices (such as night work) at the expense of others (like daytime housework). How this is worked out in reality can tell us not only something about priorities and interests in different societies but also about the relative flexibility or rigidity of 'normality' in everyday life.

\section{Not all consumers are equal}

The German Democratic Republic (GDR) was born into a particularly precarious energy situation in 1949. In addition to the destruction of plant and transport networks at the end of the Second World War and by Soviet dismantling thereafter, the new socialist country lost ready access to the hard coal (Steinkohle) deposits in the Ruhr which now lay in the capitalist West. Life and labour now hinged almost exclusively on lignite (Braunkohle), a fuel which in addition to being of low energetic value and highly polluting had the additional drawback of containing 30-60 per cent water, which spelled disaster in a cold winter because the coal froze to the ground or in transport. On top, there were constant problems with old plant, the flight and shortage of skilled workers and engineers, poorly repaired boilers and lagging production of transformers and other core parts for the generation and distribution of electric power.

On their own, coal and electricity have fundamentally different qualities: one can be stored, the other cannot. Electricity users are linked by a shared network, resulting in collective peaks and troughs very different from the coal used by separate users. However, since lignite was the main source of electricity as well as for heating homes, the fortunes of coal and electricity were intimately tied. Energy shortages vary considerably by type of fuel, duration and geographic scale. In addition, countries vary in their energy mix, relative autonomy and stage of economic development. Japan depended on hydropower for nearly 60 per cent of its electricity until 1960. Ten years 
later, 41 per cent of the country's electricity generation came from oil. Socialist East Germany, by contrast, depended on lignite for 83 per cent of its electricity in 1970. By the time the Wall came down in 1989, the East German population still relied on solid fuels for 56 per cent of all its energy needs, notwithstanding the expansion of the gas network in the 1970s-1980s. ${ }^{5}$

Shortages were a way of life in the GDR but their site shifted decisively in the course of the 1950s. Rolling blackouts had been common in both the Western allied and Soviet zones of Berlin in 1947-48. Unlike in West Germany, however, electricity cuts and rationing continued in the GDR after 1949 - West Germany did face severe gas shortages in the early 1950s, but here shortages of electricity were an anxiety rather than a reality. ${ }^{6}$ In East Germany, small rather than big users were initially expected to reduce the energy deficit. The priority was on rapid industrial recovery and growth. Industries were urged to be economical with their coal, but the main burden fell on the shoulders of household consumers. Posters, radio and the ruling Communist Party (SED) in 1951 called on the population to save for industry. As the SED central committee explained in support of its campaign for strict economy in February 1953, 'to awaken the initiative and enthusiasm among the masses for practising an energy saving regime will be an important lever to erect the foundations of socialism'. Energy saving was not a temporary emergency measure but the 'constantly intelligent principle of socialist economic policy', preventing the waste of collective resources. ${ }^{7}$ Cuts during peak hours were the norm. In March 1953, the GDR decided on a 30 per cent cut. In East Berlin, the situation was especially problematic. Not only were households here responsible for 40 per cent of all electricity used, but from 1952 East Berlin had to export energy to the rest of the GDR to help alleviate shortages there.

Electricity cuts and discontent over coal deliveries earlier that year hardly helped the public mood in the first half of 1953. In January, there had been long queues for coal. In Nordhausen, a public official was confronted by heavy engineering workers who had waited since $4 \mathrm{o}$ ' clock in the morning: 'If one is lucky, one receives $50 \mathrm{~kg}$ of briquettes after having waited four hours. ${ }^{8}$ Deliveries met targets in Berlin and Cottbus, but there were serious problems in Dresden, Potsdam, Leipzig and Karl-Marx Stadt, where inhabitants were either left short or refused to take low-grade unsieved lignite altogether. ${ }^{9}$ Lack (or uncertainty) of coal drove more and more people to switch on electric heaters instead, thus intensifying the peak problem. Overcrowding and damaged housing increased the popularity of electric hot plates; these gave lodgers the chance to cook in their own room in the evening and avoid tension with the main tenant over the use of the kitchen, one energy inspector noted. ${ }^{10}$

5 Bundesarchiv (BArch) Berlin-Lichterfelde, DF 4/32283, Institut für Energetik, 'Abrechnung der Komplexbilanz Energie der DDR 1987'.

6 "Am Ende der Gasversorgung?" in Energiewirtschaftliche Tagesfragen, III/24, 18 Feb. 1954, pp. 213214.

BEWAG Archive, Berlin, A 14: Bewag Ost, 7, director Quade 'Stellungnahme', 18 Feb. 1953.

8 BArch Berlin-Lichterfelde, DC/16/23, Kopietz to Koordinierungs- und Kontrollstelle für Industrie und Verkehr, 19 Jan. 1953.

9 BArch Berlin-Lichterfelde, DC/16/23, Abt. Grundstoffindustrie to Politbüro and ZK, 24 July 1953.

10 Landesarchiv Berlin (LAB), C Rep. 149-06 nr 28, Protokoll, Tagung der bezirklichen Energiekommission, 11 Dec. 1953. 


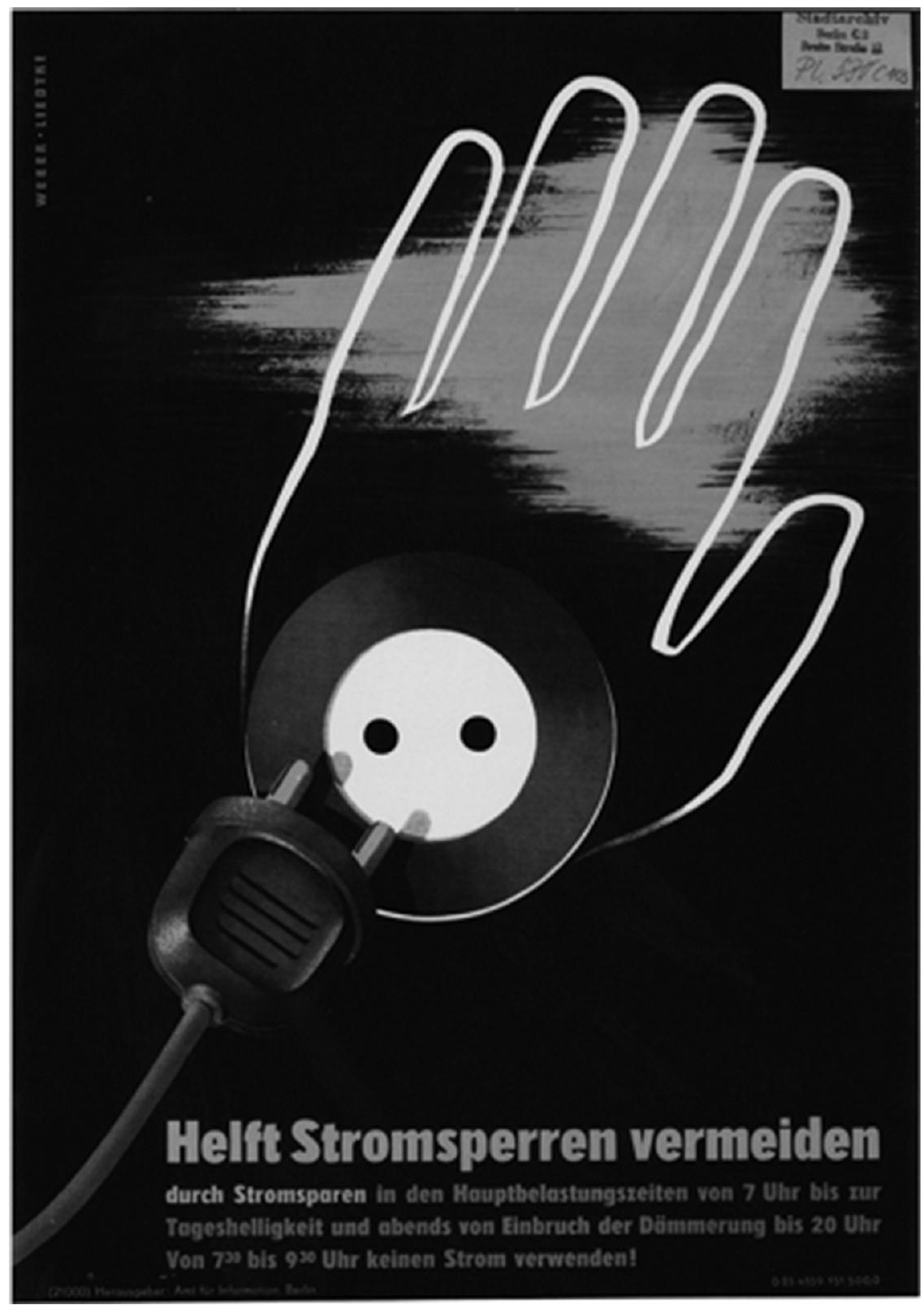

$\oplus$

Figure 15.1 'Helft Stromsperren vermeiden' 1950 ['Help prevent power cuts', Berlin 1950]. Source: Berlin, Landesarchiv. 


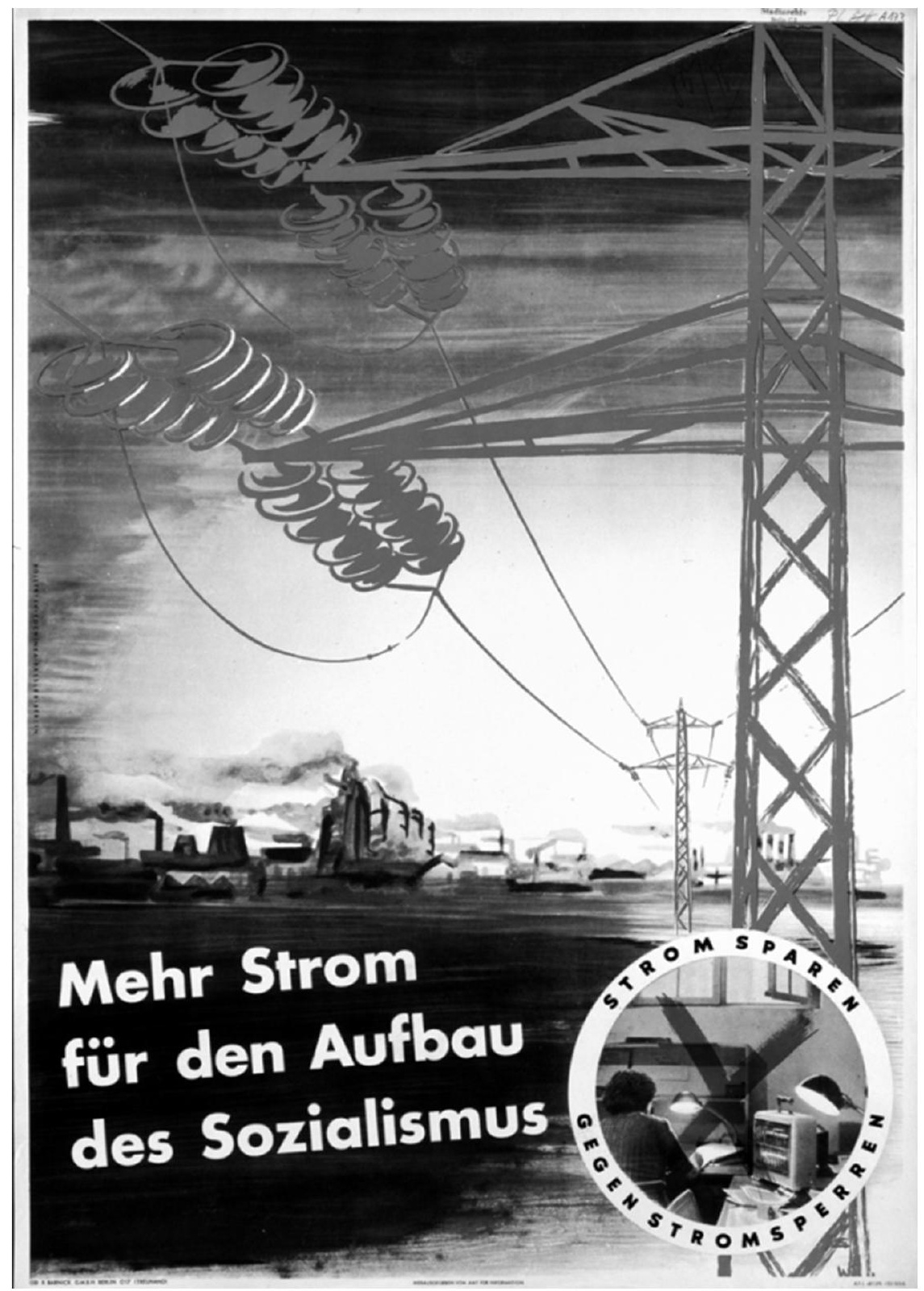

(1)

Figure 15.2 'Mehr Strom für den Aufbau des Sozialismus' 1952 ['More electricity for building socialism', East Germany 1952]. Source: Berlin, Landesarchiv. 
The uprising of 17 June 1953 tipped the balance between industry and households. The main demands of the protesters had been free elections, more humane work quotas and better living conditions. The regime would not give them the first two. But it now made it a priority to give them energy. A week after Soviet tanks had quelled the uprising, the council of ministers ordered the end of electricity cuts (Stromsperren) for households, with effect from 1 July. The population was already spared any cuts in the following week. Then levels of consumption started to rise and made it necessary to roll out cuts again in July and early August. The state secretary for energy blamed industries that 'refused' to switch to night shifts but also the more liberal use of energy in households; total energy use jumped from 2,698 MW to 2,912 MW in the course of July, requiring cuts of between $100 \mathrm{MW}$ and $300 \mathrm{MW}$ in these weeks. ${ }^{11}$ The campaign for greater energy awareness never entirely disappeared. In 1954, at 7 am in the morning, lorries would drive through the streets of East Berlin, with loudspeakers appealing to residents to 'Remember that we are now in peak time: save energy.' ${ }^{12}$ Energy saving was promoted in film and leaflets. In 1957-58, the party's youth movement (FDJ) initiated a campaign against the 'Wattfrass' (watt glutton) that carried echoes of the Hitler Youth's earlier pursuit of the 'Kohlenklau' (coal thief). Members pledged to switch off electricity-hungry appliances in their homes and schools and save at least $100 \mathrm{~W}$ each; ${ }^{13}$ that citizens were reckless 'energy sinners' would remain a complaint among local energy deputies in the 1950s and 1960s. But the political will for more stringent measures had disappeared. The political masters had no desire to confront the people and enforce energy discipline within their private four walls.

This left industry as the main site of intervention. The main lever was electricity quotas for peak hours for consumers using more than $500 \mathrm{KW}$. Energy deputies (Energiebeauftragte) worked on behalf of local government districts (Räte). In addition, there were energy inspectors within enterprises. Some firms excelled. The VEB Berliner Glühlampenwerk, the publicly owned light-bulb producer, was praised as 'exemplary' by the district inspector in February 1962. The firm had appointed its own full-time energy inspector who checked that quotas were not exceeded, with the help of hourly meter readings and half-hourly studies of electric curves. A specially designed clock sounded a signal when quotas were being reached. Excessively large engines were replaced. In 1961, the plant spent 30,000 marks on the cleaning of existing lights. It whitewashed rooms to reflect light better. For every shining example, however, there was a failure not very far away. The VEB Fahrzeugausrüstung - a vehicle equipment plant - did not even have a schedule for the operation of its machines. It repeatedly breached both electric and gas quotas. The energy delegate was unqualified and 'seen as a brake on the production process'. For many foremen, energy delegates were 'deceitful' and a pain in the neck, pointing out pipes that were not insulated, criticizing fellow workers for opening windows and interfering with work routines. ${ }^{14}$

BArch Berlin-Lichterfelde, DC/16/23, Stellungnahme, Büchner, 3 Aug. 1953.

12 Energiewirtschaftliche Tagesfragen, III/24 (1953-4), p. 235.

13 LAB, C Rep. 135-01, no. 253, Protokoll über die Kohle- und Energiekonferenz, 6 Feb. 1958.

${ }^{14}$ LAB, C Rep. 135-01, no. 253, Schmiga, Informationsbericht über die Versorgung mit Elektroenergie', 14 Feb. 1962; see also ibid.: Andrae to mayor and ZK, 24 Nov. 1961. 
The mixed career of the local energy deputies illustrates the problems of making energy a greater priority in a planned economy. Energy deputies were first appointed in 1952. A year later, an official investigation found few were living up to the job. Deputies were used for all sorts of other tasks where there was a shortage of officials and resources. The one in Fürstenwalde registered the sale of livestock. In Magdeburg, many were also in charge of collecting scrap metal. Those in Stendal and Calau had qualifications but as a barber and brewer. Most industries either did not have any energy plans or lacked the meters and instruments to monitor them. In the newly christened Karl-Marx-Stadt (today's Chemnitz), the chair of the city council was not even aware of the energy delegates' existence. In Neubrandenburg, shops and retailers did not know that it was prohibited to light shop windows during peak hours. Most firms simply refused to take part in 'socialist competitions' (sozialistischer Wettbewerb) for energy saving. ${ }^{15}$

In November 1953, the Ministry for Heavy Industry tried to give the status of the lowly energy delegates a lift with new ranks and uniforms - a grey blue jacket and trousers, with beige for special festivities, and piping rising from bronze to gold for officials in ministries. The new clothes failed to impress. In June 1954, the frustrated energy delegate in Berlin Weissensee was still waiting for forty-eight enterprises to provide their energy consumption cards, documenting their electricity consumption. ${ }^{16}$ By the late 1960s, the government found few signs of improvement. In Karl-MarxStadt, for example, 1,095 enterprises had pledged energy-saving measures. In Leipzig, on the other hand, 39 per cent of enterprises did not have any energy plan, and 20 per cent did not use any energy norms for their own production plans. In Berlin, only every third firm entered the energy strand of socialist competitions. ${ }^{17}$

The frustrations of the energy delegates were endless and point to the systematic difficulties of managing scarcity, let alone overcoming it. On 1 October 1954, for example, Berlin's mayoral office explained to the local districts that the present shortage could not just be blamed on yet another technical failure at the Klingenberg power station but resulted from industries feverishly trying to overcome their planning backlog. ${ }^{18}$ Energy delegates called for fines, only to see these softened or thrown out by local government. As the lawyer for the VEB Grossdrehmaschinenbau stressed in his appeal to the council in February 1955, the mechanical engineering enterprise produced vital exports for the USSR. Yes, it had repeatedly exceeded its electricity quotas in October of the previous year, but it had no option, given the delays and fluctuations with raw materials. To slow down production when materials finally arrived and fail to meet export orders purely to stay within energy norms was unreasonable. The fine for the director was transmuted into a 'stern warning.. ${ }^{19}$ Other firms burnt through their monthly electric peak-use quota well before the end of the month with the simple

${ }^{15}$ BArch Berlin-Lichterfelde, DC 16/21: Staatssekretariat für Energie, HV Energie, Zentrale Kommission, report 13 May 1953.

16 LAB, C Rep. 148-06, nr 43, Wehlmann, Tätigkeitsbericht 17 June 1954.

17 BArch Berlin-Lichterfelde, DC 20/11885, Opitz to Rauchfuss, 14 Nov. 1969.

18 LAB, C Rep. 148-06, nr 43, Harry Krebs to council of district Berlin-Weissensee, 1 Oct. 1954.

19 LAB, C Rep. 148-06, nr 43, Gaulke to VEB 16 Dec. 1955. 
realization that energy, once used, could not be clawed back. ${ }^{20}$ In general, it did not matter how many new power stations the GDR built and how much it increased the supply of coal - the amount of lignite doubled in the 1960s - energy continued to be outpaced by industrial production. Energy was too cheap to encourage saving - only in 1968 did the GDR government introduce a higher price for peak-time electricity for heavy users, coupled with a feed-in tariff to reward those who fed energy back into the grid during peak time. ${ }^{21}$ Energy scarcity was a normal feature of an economy marked by general material scarcity.

Local authorities were in an ambivalent position. Officials were consumers of energy as well as arms of the government. In December 1952, police reported that the lights were always on in 8,000 buildings managed by the state-owned housing administration..$^{22}$ A year later, the government prohibited the public and private use of electric space heaters between the hours of 6 am and $10 \mathrm{pm}$, but could not even enforce it among its own officials. In October 1954, the ruling party made the Berlin electricity provider BEWAG sent out a '50-Mann Brigade' to do spot checks on 155 government offices and eighty-nine enterprises: it discovered 377 electric radiators, of which 205 were running (in early October!), and thirty-one cookplates, of which two were used as heaters. Many offices had a well-oiled early warning system for such inspections and managed to hide away their appliances in time. ${ }^{23}$

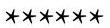

Japan faced an even more frightening challenge in the post-war period. Defeat isolated Japan from international energy supplies. Domestic coal production collapsed at the end of the war, yielding only 23 million tonnes in 1946, compared to 49 million tonnes in 1938. ${ }^{24}$ Traditional fuel resources had also been depleted, as deforestation during the war had eaten into already limited domestic resources of firewood and charcoal; Japan lost 15 per cent of its forest in the course of the war. ${ }^{25}$ Desperate to overcome fuel shortages, domestic consumers turned to electricity. There were few alternatives; charcoal rations had been curtailed and gas supply was unreliable because of reduced coal production and damaged gas mains. In 1946, electricity consumption for lighting and domestic purposes jumped to $63 \mathrm{TWh}$, nearly twice the figure during the war. There was an additional $20 \mathrm{TWh}$ of illicit use, ranging from electricity theft to the installation of unauthorized appliances and higher wattage light bulbs. ${ }^{26}$ Since 90 per cent of Japan's electricity at the time came from hydropower, shortages were inevitable

${ }^{20}$ LAB, C Rep. 148-06, nr 43, Hohmann, Tatigkeitsbericht, nd (Sept. 1956).

${ }^{21}$ BArch Berlin-Lichterfelde, DY/30/J IV 2/2J, Ministerrat, Beschluss 10 Sept. 1968.

22 LAB, C Rep. 106-02, nr 616, Protokoll, Energiekommission 2 Dec. 1952.

${ }^{23}$ LAB, C Rep. 752, nr 38, Energiekommission, Kurzbericht, Oct. 1954.

${ }^{24}$ Shōwa Kokusei Sōran, Vol. 1 (Tokyo, 1991), p. 460.

25 William Tsutsui (2003), 'Landscapes in the Dark Valley: Toward an Environmental History of Wartime Japan', Environmental History, VIII: 294-311.

${ }^{26}$ S. Kotake (1980), Denryoku Hyakunen Shi Zen hen, p. 620, Tokyo; M. Tanahasi (1948), Denki Senyō Bōshihou Yōtei, p. 5, Funabashi. 
in unusually dry seasons. A series of winter droughts between 1946 and 1952 made electricity crises a regular event. In 1946, electricity was added to the list of controlled resources that already included charcoal and firewood. For the Japanese government under the American Occupation, the overwhelming priority was economic recovery. Under the 'priority production policy', available energy was thus directed to industries - particularly coal and steel - at the expense of domestic consumers. ${ }^{27}$

The control of electricity supply was ad hoc and arbitrary. Because electricity supply largely depended on rainfall, the extent of necessary saving tended to be difficult to predict. In August 1948, Kanto Electric Supply announced that the month's electricity supply would be reduced by 10 per cent, 25 per cent or more from the previous year's level..$^{28}$ Voltage reduction and power cuts were executed without warning, especially in residential areas.$^{29}$ Both the occupying American authorities and Japanese civil servants believed that turning off electricity in households to deliver fuel to factories was justified to make the country stand on its own feet. This was a top-down - even authoritarian - approach. U.S. officials opposed the formation of voluntary energy-saving groups for fear of reviving wartime patriotic associations or spreading socialism..$^{30}$ Instead, savings in household consumption were achieved through compulsory measures, such as disconnection or setting ceilings for consumption, that were monitored by meter readers and supply companies' patrols. ${ }^{31}$ Industries, by contrast, had their electricity allocated and maximized their use through efficiency, such as thermal management in the steel industry. ${ }^{32}$ Osaka city sent electricity rationalization instructors to factories. ${ }^{33}$

The main site of intervention for Japanese policymakers, however, was the residential sector. Households were told to use only 'one lamp, [and] one radio' during peak hours. ${ }^{34}$ Between 1949 and 1953, the Resource Investigation Council widened its ambitions well beyond electricity cuts. The Council, for example, recommended shifting demand from electricity and charcoal to town gas in urban areas and replacing in rural areas traditional cook stoves (kamados) altogether. ${ }^{35}$ The number of town gas consumers increased from 1.2 million in 1948 to 2.2 million in $1954 .{ }^{36}$ The rural cooking reform was introduced in 43,000 villages.

Although the sites of intervention were different in Japan and the GDR, energy disruption dramatically affected everyday life. In Japan, intervention hit domestic

${ }_{27}$ For example, the 'Electric Power Five Year Plan' referred to in H. Inaba (ed.) (1948), Nihon Keizai no Shōrai, pp. 166, 287, Tokyo.

28 Denki Shimbun, 9 Aug. 1948.

29 Ministry of Commerce and Industry, 'Kinkyū Denryoku Chōsetsu Jissi Youryō', 10 Nov. 1947, National Archives of Japan.

${ }^{30}$ Tokyō Denryoku (1983), Tōkyō Denryoku Sanjyūnen Shi, p. 159, Tokyo.

${ }_{31}$ Tokyō Shōkō Kyoku (1948), Juden no Tebiki, Tokyo.

32 S. Kobori (2010), Nihon no Enerugī Kakumei, pp. 135-144, Nagoya.

33 Denki Shimbun, 9 Aug. 1948.

34 Taro Ishikawa (1999), Chūbu no Denki Bunka no Ayumi Tenbyō, p. 198, Nagoya.

35 Traditional cooking stoves had 17-18 per cent thermal efficiency, while improved cooking stoves had 24-25 per cent efficiency. Shigen Chōsa Kai (1953), Katei Nenryō Gōrika ni kansuru Kankoku, pp. 5, 39, Tokyo,.

${ }^{36}$ Ministry of Internal Affairs and Communications (2006), Historical Statistics of Japan, new edn., Vol. 2, p. 570, Tokyo. 
consumers directly. ${ }^{37}$ In the GDR, by contrast, the primary focus after the 1953 uprising was on the industrial workplace. Of course, this did not mean that daily life and domestic use were untouched. Additional night shifts upset daily rhythms of cooking, washing and childcare, affecting women and mothers especially. We now turn to the temporal manifestations of energy disruptions.

\section{The politics of time}

Energy shortages are interesting cases of scarcity because they illuminate transfers of limited resources not only between groups but also across time. In this section, we focus on two types of such temporal transfers: efforts to move energy use out of peak times (a characteristic of grid systems) and responses to severe seasonal shortages affecting bundles of fuel, such as coal, water and electricity.

Japan's post-war energy policy rested on assumptions about the 'normal' time for work and domestic life. Policymakers and energy providers believed that daytime was for productive work, while the evening belonged to family life. These were powerful social and cultural conventions rather than official regulations. ${ }^{38}$ Temporal management of industrial demand was rarely attempted unless electricity supply became extremely tight. ${ }^{39}$ Electricity quotas for industry consumers were not intended to alleviate peak load. It was only after 1953 that large factories were offered off-peak pricing to incentivize operation outside peak hours. There was little official control over the temporal pattern of electricity consumption in factories and business offices.

In real life, it proved impossible to expect cultural conventions to split electricity use neatly into day- and night-time activities. To prepare dinner in time for the return of workers, cooking in the home had to start before the evening; a typical load curve in this period had a pronounced peak between $5 \mathrm{pm}$ and $8 \mathrm{pm} \cdot{ }^{40}$ Restaurants, bars and entertainment districts also opened for business around $5 \mathrm{pm}$, boosting electricity load. Some factories kept operating into the evening. In the Kanto region, for example, 25 per cent of industrial consumers exceeded their allocation between September 1951 and January $1952 .{ }^{41}$ Factories also offered their workers baths, cooking facilities and even permanent hair wave machines, which drew additional electricity outside work hours. ${ }^{42}$

37 Takuji Okamoto (2001), 'The Reorganization of the Electric Power Industry', in Shigeru Nakayama, Kunio Goto and Hitoshi Yoshioka (eds.), A Social History of Science and Technology in Contemporary Japan, Vol. 1, pp. 323-324, Melbourne.

38 Barbara Molony (1993), 'Equality versus Difference: The Japanese Debate over "Motherhood Protection", 1915-50', in Janet Hunter (ed.), Japanese Women Working, p. 141, London.

39 An exception was an official order in November 1947 that prohibited industry electricity use between $4 \mathrm{pm}$ and $10 \mathrm{pm}$. Ministry of Commerce and Industry, 'Kinkyū Denryoku Chōsetsu Jissi Youryō', 10 Nov. 1947, National Archives of Japan.

40 Nihon Hassō Den, 'Kinkyū Seigen no Jitsujyō Chōsa', 10 Oct. 1948, Central Research Institute of Electric Power Industry, Nippatsu Library, Tokyo; Chugoku Denryoku (1996), Kaisō p. 239, Hiroshima.

${ }^{41}$ Kantō Denki Kyōkai (1952), Denki Gasu Jigyō Nenpō, p. 77, Tokyo.

42 Denki Shimbun, 27 Aug. 1948. 
The competing demand for energy caused frequent evening blackouts. Instead of being privileged users in the evenings, it was often households that had to carry the burden of disruption. Reports in the Housewives' Association's (Shufu-ren) newsletter highlighted how blackouts ruptured the normal rhythm of everyday life. Housewives complained that blackouts slowed down meal preparation, leaving them with disgruntled husbands and crying children who were afraid of the dark.$^{43}$ Household fuel was one of the association's crusading issues. In November 1950, it secured over 6,600 tonnes of charcoal for its members. ${ }^{44}$ In early 1952, blackouts drove the association to take political action, and its delegates were sent to government offices and utilities companies, demanding better management of electricity supply. Negotiations between the association and the Public Utilities Commission resulted in a 2 per cent cut of the electricity tariff, pro rata for days when a power cut of more than two hours occurred. ${ }^{45}$

Small discounts on utility bills, however, did not appease the association. When blackouts continued later in 1952, it organized a mass boycott against electricity bills. The movement attracted one million supporters, ranging from domestic consumers to small businessmen running cinemas, beauty salons, laundry shops and medical clinics. The utility companies initially threatened disconnection and penalties for late payment, but the association held its ground. After three months, the companies yielded and agreed to reduce customers' utility bills in proportion to the number of power cuts. ${ }^{46}$

The housewives' protest illustrates the gendered response to energy disruption in post-war Japan. Following the wartime emphasis on women's role on the home front (Jugo no Mamori), the post-war shortages of food and fuel highlighted the role of housewives in procuring necessities. In a contemporary photograph, a drawing of an electricity bulb was overlaid on the association's rice-paddle-shaped placards, showing that, for the association's members, electricity was as essential as food (Figure 15.3). Being tasked with ensuring a bright and warm home in the evening, Japanese housewives saw evening power cuts as a threat to family life.

The Japanese story brings into view deep-seated assumptions about 'normal' customs and habits and about what were considered acceptable forms of intervention in the organization of work time versus domestic time. East Germany picked a radically different course. Here the focus was on enterprises and on getting industrial users to save energy at peak time by introducing additional shifts in evenings and night-time. In January 1954, VEB Siemens-Plania, for example, won the first prize in the competitive 'battle against electricity cuts in the GDR' for managing to use 55 per cent of its entire electrical energy in night-time. But there were clear limits, not least since many enterprises in the steel and chemical industries were already running three shifts. Encouraging firms to make use of their night-time quotas also had bizarre counter-effects that will be familiar to students of planned economies. In spring 1953, for example, the Magdeburg Konsumkleiderfabrik (clothing factory) was found to

\footnotetext{
${ }^{43}$ Shufu-ren Tayori, 15 Jan. 1952 and 15 Nov. 1952.

${ }^{44}$ Shufu-ren Tayori, 1 Nov. 1950.

45 Shufu-ren Tayori, 15 Mar. 1952.

46 Shufu-ren Tayori, 15 Feb. 1953.
} 
be fully lit at night to reach its night-time electricity target, even though only four employees were at work. ${ }^{47}$

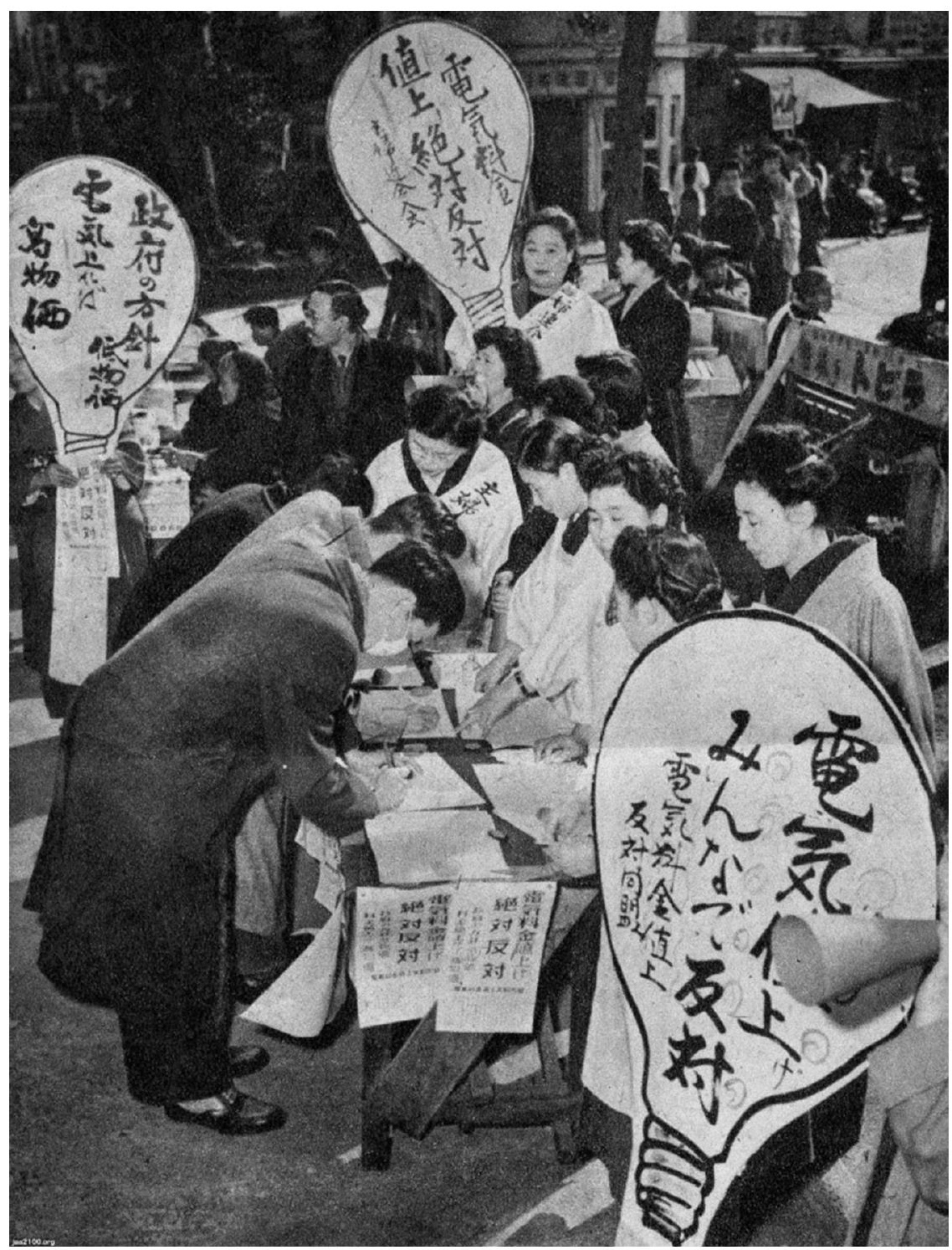

Figure 15.3 Housewives' Association protest against electricity tariff increase (1954). Source: Japan Archives, Hygo.

47 BArch Berlin-Lichterfelde, DC 16/21: Staatssekretariat für Energie, HV Energie, Zentrale Kommission, report 13 May 1953. In general, see: André Steiner (2004), Von Plan zu Plan: eine Wirtschaftsgeschichte der DDR, München. 
In 1961, after years of pressure and intervention, the night-time share of electrical consumption in Berlin stood at 23 per cent (up from 20 per cent in 1960), ${ }^{48}$ a considerable but hardly impressive figure and certainly not sufficient to eliminate the peak problem. Many enterprises routinely exceeded their energy quotas in the evening peak by 30 per cent, like the VEB Werk für Fernmeldewesen (telecommunications) in 1962. ${ }^{49}$ A spot check of 120 enterprises in October 1963 revealed that only forty-five had moved their work hours, affecting 8,500 workers, including 2,800 women. The National Economic Council concluded that 'this was in no way satisfactory, given all the effort..$^{50}$ One third of the enterprises said they had not even received the energysaving guidelines.

Peak-time restrictions also seriously affected agricultural work rhythms. In November 1953, for example, the use of electric energy was prohibited during the hours of 6 am and $1 \mathrm{pm}$ and, again, from half an hour before sunset until $10 \mathrm{pm}$. Electrical fodder steamers were only to be switched on between $10 \mathrm{pm}$ and $6 \mathrm{am}$.

These temporary introductions of additional shifts and night-time work had major repercussions for the coordination of all sorts of other daily routines and rhythms as workers suddenly had their work, leisure and sleep patterns disrupted. Women workers with children were especially affected - the official protection of mothers and teenagers from the consequences of night-shifts was simply being ignored. Additional shifts required nurseries to stay open longer. In administrative offices, peak-hour restrictions limited the flexible use of overtime. On 15 December 1953, for example, the energy delegate in Berlin Pankow reminded officials that it was strictly forbidden to keep working after $5 \mathrm{pm}$ in order to catch up on planned targets: employees were told to use Saturday afternoons. ${ }^{51}$ There appears to have been surprisingly little conscious reflection on the spillover of interventions at work for domestic life and leisure.

The response of the population to appeals to change their habits in peak times was muted. Few were responsive to radio alerts and newspapers publicizing peak hours; indeed, many professed (or preferred) not even to be aware of their existence. An energy delegate in Berlin Pankow in December 1954 found that most workers were reasonably economical; he blamed the high energy use on a minority of the bourgeois intelligentsia, who lacked the will to 'sacrifice their personal comforts. ${ }^{52}$ Pointing the finger at the class enemy was probably too simple. At a SED conference on the energy programme in Berlin in October 1957, Else Kuss, a deputy of the Democratic Women's League (Demokratischer Frauenbund), reported that none of her neighbours had followed the exhortation to reduce the use of appliances during peak hours. ${ }^{53}$ The spread of electric heating and electrical appliances put an additional strain on an already fractured energy system and proved difficult to deal with for a socialist regime

\footnotetext{
${ }^{48}$ LAB, C Rep. 135-01, nr 253, Schmiga, 'Informationsbericht über die Versorgung mit Elektroenergie', 14 Feb. 1962.

49 LAB, C Rep. 135-01, nr 253, Andrae to SED, mayor and ZK, 24 Nov. 1961.

${ }^{50}$ LAB, C Rep. 135-01, nr 253, Aktenvermerk, 14 Oct. 1963.

1 LAB, C Rep. 149-06, nr 28, Sielaff to chair of Pankow council, 15 Dec. 1953.

52 LAB, C Rep. 149-06, nr 28, Sielaff to Magistrat, 8 Dec. 1954.

3 LAB, C Rep. 902, nr 139, Kuss at SED conference, 3 Oct. 1957.
} 
which saw energy (like water) as a basic need. Further restrictions followed in the late 1950s.

The range of infractions and disregard might be read as 'ruses' in the tradition of Michel de Certeau, little everyday acts of resistance. ${ }^{54}$ This probably would be an overinterpretation. Habits were resilient, shaped in part by infrastructure and equipment or by their absence..$^{55}$ Even if people had wanted to heed the appeals of the $70 \mathrm{~W}$ and $100 \mathrm{~W}$ campaigns in the 1950s, there were simply not enough of the lauded $15 \mathrm{~W}$ or $25 \mathrm{~W}$ light bulbs for sale to dim their living rooms. In poorly heated blocks of flats, the electric heater was a welcome friend. With single-pipe heating systems and in the absence of thermostats, it was natural for most residents to open their windows to regulate the temperature - even after insulation and central heating programmes from the 1970s, there were 1 million homes without any thermostat in $1983 .{ }^{56}$ In the early 1980s, a directive required users to hand over all electrical heaters and night-storage heaters unless they held a licensed exemption. Between 1982 and 1984, this succeeded in lowering the connected wattage of direct electric space heaters by 46 per cent or 268 MW and that of night-storage heaters by 13 per cent or $66 \mathrm{MW}$. Still, only one-third of electric heaters were handed back in. Energy combines received tens of thousands of applications for exemptions and only a quarter of these were rejected. ${ }^{57}$

Prolonged seasonal disruptions produced distinctive predicaments and reactions in East Germany. The situation was particularly tense in the autumn and winter of 1958, in the winters of 1963 and 1970/71 and in the autumn of 1971. In September 1958, grid problems led to many districts and rural populations in particular being cut off. Heavy snow in January 1963 saw coal wagons stuck in snow and Berlin and other cities without supplies. On 14 January 1963, Berlin ordered hot water to be limited to the period from 12:00 on Saturday to 12:00 on Sunday, including on the prestigious Karl-Marx-Allee; to restrict hot water to a few hours every day was rejected as wasteful because it would have required repeatedly heating up boilers. Some schools were closed, others ran shifts in one room, heated to a minimum. Firms and institutions were ordered to move staff into the same office; nurseries and medical buildings were exempted. Industrial and commercial use of gas was lowered to 50 per cent of the volume normal for that time of year. ${ }^{58}$ In 1971, the 'week of winter preparation' began as early as 18 October.

Seasonal shortages led to the general mobilization of the population, with students and soldiers sent to mines and helping to defrost tracks and coal wagons. The National Front (NF), assisted by the FDJ youth organization, was the regime's voice at street level. In January 1963 in Erfurt, it mobilized 1,160 activists to get scarce coal to

${ }^{54}$ Michel de Certeau (1984), The Practice of Everyday Life, Berkeley, CA; cf. Vanessa Taylor and Frank Trentmann (2011), 'Liquid Politics: Water and the Politics of Everyday Life in the Modern City', Past and Present, 211: 199-241.

55 See Frank Trentmann and Anna Carlsson-Hyslop (2018), 'The Evolution of Energy Demand: Politics, Daily Life and Public Housing, Britain 1920s-70s', Historical Journal, 61 (3): 807-839.

56 BArch Berlin-Lichterfelde, DC20/27420, AG Rationelle Energieanwendung, Vorlage, 27 June 1984.

57 BArch Berlin-Lichterfelde, DC20/27420, AG Rationelle Energieanwendung, Vorlage, 10 Feb. 1984.

${ }^{58}$ LAB, C Rep. 135-01, nr 253, Hornig to Hoeding, 'Massnahmen in der Kohleversorgung', 14 Jan. 1963. 
suffering households and drum up support for energy saving. Unsurprisingly, the reports by the NF showcase the enthusiasm of their volunteers but they also give some insight into the reactions of the public. In Erfurt, inhabitants of the flats on Triftstrasse 48, 49a and 50 pledged to save energy - presumably, those living in numbers 1 to 47 were less heroic. The NF set up 13 Wärmestuben (warm chambers) for Erfurt pensioners, who were entertained by Young Pioneers and actors whose theatres had closed. How attractive these were is doubtful: in Rostock in 1963 often no more than two to four pensioners found their way to them..$^{59}$ Internal reports by the NF registered considerable popular frustration. People saw the latest shortage as evidence that 'the GDR was near collapse', others wondered 'why do our newspapers report about the poor conditions in capitalist countries but so little about ours?'60 In January 1971, in Suhl, some Hausgemeinschaften (block communities) offered suggestions about how to save energy, from unscrewing light bulbs in chandeliers to lowering the light in staircases. The same meetings, however, also revealed scepticism about such individual responses to systemic problems. 'Why is the energy situation getting worse and worse every year', asked one. Many voices asked 'why have not more power stations been built' and 'why has there not been more investment in energy'. A 'Brigade' of the PGH 'Figaro' (hairdressers) complained: ' 21 years GDR and still not enough electricity. ${ }^{\text {'1 }} \mathrm{A}$ collective farmer put it bluntly: 'now again, the GDR has run out of coal: it is all the fault of socialism.' ${ }^{2}$ In Rostock, shops kept selling hot water boilers - against orders. In most cases, officially sponsored local efforts at energy saving were short-lived. Erfurt and the surrounding area measured the response to the FDJ's campaign on 29 January 1963 to dim lighting and to turn off electrical appliances. There was an immediate saving of 8 per cent of electricity in Erfurt and 5 per cent in Gotha compared to 25 January, but the following day consumption jumped back up by 3 per cent and 7 per cent, respectively. ${ }^{63}$

In contrast to the GDR, Japan in the 1950s wholeheartedly embraced affluent lifestyles. Already before regaining independence in 1952, Japan's electricity industry was restructured into nine regional monopolies. The nine electric power companies soon started to fend off official restrictions as interfering with private business. As commercial operations, they also began to take a more conciliatory stance towards domestic consumers. A rapid series of tariff increases could only be justified by raising customer satisfaction. Between 1951 and 1956, national electricity consumption grew from 37 TWh to 61 TWh. The diffusion of the so-called three sacred treasures - blackand-white television, the washing machine and the refrigerator - was now locking Japanese households into the electricity grid. Industrial electricity consumption saw an even larger jump, with a boom in the chemical, steel and metal industries, and added to the pressure on energy providers. Northern parts of Japan were especially hit by electricity shortages, because the relatively low price of electricity there had attracted

\footnotetext{
59 BArch Berlin-Lichterfelde, DY 6/4678, Nationale Front, report, Rostock, end of Jan. 1963.

${ }^{60}$ BArch Berlin-Lichterfelde, DY 6/4903, Nationale Front, report, Erfurt, 31 Jan. 1963.

${ }_{61}$ BArch Berlin-Lichterfelde, DY 6/4990, Nationale Front, report, Suhl, 11 Jan. 1971.

62 BArch Berlin-Lichterfelde, DY 6/4678, Nationale Front, report, Rostock, end of Jan. 1963.

${ }_{63}$ BArch Berlin-Lichterfelde, DY 6/4903, Nationale Front, report, Erfurt, 31 Jan. 1963.
} 
new electrolysis plants and electric furnaces. In January 1957, rainfall was 20 per cent lower than average, leading to a nationwide electricity shortage. Disconnecting domestic consumers was no longer the utilities' preferred method for managing scarcity. Instead, many large industrial customers were now obliged to reduce their consumption in exchange for off-peak pricing. Large factories were the first to lose electricity, followed by voluntary reductions in smaller firms. The priority of industrial over domestic consumers had been reversed.

The change in Japan's approach to disruption coincided with a major energy transition. Japan's entry into the international oil market in 1951 stimulated investment in thermal power plants. The opening up to oil imports from the Middle East in 1964 meant that electricity supply was now stabilized by oil-fired power plants. ${ }^{64}$ Kerosene and liquid petroleum gas (LPG) further eased the pressure on household energy supply, especially for heating and cooking. By the end of the 1960s, kerosene and LPG met about half of all household energy requirements.

But the conversion to oil came at a price. In 1971, when 92 per cent of its primary energy came from abroad, policymakers realized that any disturbance in the international oil market would jeopardize the country's entire energy supply.

On the surface, Japan's domestic energy consumers in the 1960s enjoyed an energyintensive lifestyle enabled by cheap imported oil and expanded electricity supply. Most energy users believed disruption was a thing of the past. In reality, they were living in the shadow of energy disruption. A new type of vulnerability was emerging as a result of two factors. The first was Japan's excessive dependence on imported oil. The second was that electricity demand growth exacerbated the peak load problem. By 1970, around 90 per cent of Japanese households had a washing machine, electric refrigerator and television set, and about 70 per cent owned an electric vacuum cleaner. Between 1961 and 1971, domestic electricity consumption almost quadrupled, from 15 TWh to 56 TWh per annum. And the diffusion of colour televisions and air conditioners in the late 1960s shifted the country's annual peak demand from winter to summer. In early August 1971, the country was on the verge of new electricity restrictions. The utilities tried to prevent government intervention by controlling industrial demand. Almost 1,400 firms responded to the Kansai Electric Power Co's demand reduction campaign, which eased pressure from the supply network. The narrow escape was repeated in the following year.

In the 1960s, domestic electricity users temporarily disappeared from the Japanese story of energy disruption. No longer were they targeted first at moments of energy shortage. For them, blackouts now belonged to the realms of exceptional circumstances such as typhoons, floods and earthquakes. The electricity supply was far more reliable than in previous decades. ${ }^{65}$ That new 'normality' made domestic consumers complacent about the risk of disruption. In 1971, with the prospect of large-scale blackouts looming over Japan, the journalist Tokuro Irie observed that 'Japanese people are inclined to believe that they have a limitless supply of water, liberty and electricity.66

${ }^{64}$ Japan's electricity supply industry, in 1968, consumed more than 30 million kilolitres of heavy and crude oil for generating power.

65 Ministry of International Trade and Industry (1970), Electricity White Paper, p. 243, Tokyo.

${ }^{66}$ Töden Graph, Aug. 1971. 


\section{Outlook}

Disruptions offer an unusual lens for the study of developed societies, which are normally treated as functional and productive, societies that 'work' and follow a script from which societies suffering from famine, internal strife and underdevelopment deviate. However, developed societies have also faced disruptions, and studying these can shed light on the inner workings of societies that tend to take basic services for granted. Rather than treating shortages as aberrations, we can view them as facilitating the production of a new normal. ${ }^{67}$ It was shortages of coal and charcoal, for example, that pushed many people to electric heaters and cookers, moving these societies one step closer to an electrified world of consumption, with its inherent vulnerability and dependency.

Reflecting on energy disruptions in the past is an opportunity to reconceptualize energy scarcity in the present. Conventionally, research on energy disturbance has been preoccupied with supply-side problems, chiefly those resulting from technological failures and human errors. ${ }^{68}$ However, as the sociologists Hugh Byrd and Steve Matthewman have recently argued, energy disruptions in modern societies largely stem from a failure of 'exergy' - the amount of energy available for use. ${ }^{69}$ Energy becomes scarce when supply and demand fail to synchronize. Put differently, energy disruption is a loss of energy flow when demanded by users. The level of disturbance thus correlates with the mismatch between available supply and the demand involved in users' pursuit of what they perceive to be a 'normal' life. Since the nature of this 'normality' changes over time, and especially so in modern consumer societies - think of heating, cooling and mobility - the demand of daily practices and expectations needs to be recognized as a critical factor in the creation of energy shortages. This chapter has revealed how consumer expectations of energy use hinged upon energy users' daily routines, assigned to specific times of the day by social and cultural norms and conventions. Consumers, we have shown, were particularly sensitive to disruptions in their core routines, such as sleeping, eating, working and leisure. Modern energy systems have not eliminated disturbances. In fact, they have often made them more frequent and left users more vulnerable than in the past. ${ }^{70}$ It is therefore just as crucial to build user-side resilience as it is to improve the technical reliability of supply. A first step towards mitigating the impact of future disruptions will be a better understanding of how time-anchored daily routines spread the impact of disruption to diverse social activities. This question is only becoming more urgent as societies are expanding their use of renewable energy, such as solar, wind and tidal power - resources that are susceptible to supply fluctuations caused by natural temporal cycles and deviations.

${ }^{67}$ See also Hendrik Vollmer (2013), Sociology of Disruption, Disaster and Social Change: Punctuated Cooperation, Cambridge.

${ }^{68}$ For example, U. G. Knight (2001), Power Systems in Emergencies: From Contingency Planning to Crisis Management, p. 7, Colchester.

${ }^{69}$ Hugh Byrd and Steve Matthewman (2014), 'Exergy and the City: The Technology and Sociology of Power (Failure)', Journal of Urban Technology, 21 (3): 85-102.

70 Byrd and Matthewman, 'Exergy and the City', pp. 97-98; Charles Perrow (1984), Normal Accidents: Living with High-Risk Technologies, updated edn., Princeton, NJ. 
Responses to energy disruption are historically and politically contingent. What emerges are forms of material politics that develop in conjunction with a constantly changing energy mix. Their development is dynamic and interdependent. At the same time as they eliminate some bottlenecks, new fuels and new technologies create new kinds of vulnerability. Resilience to disruption is conditioned by political regimes and their citizens' coping mechanisms as well as by the availabilities of different fuels.

One striking thing about the history of energy disruption in the GDR and Japan is the way political regimes and consumers helped shape supply and supply shortages. Political ideas determined the official distribution of energy in the first place, by prioritizing certain types of consumers over others. However, consumers were not necessarily the obedient servants of their political masters. Consumer resilience and outright political mobilization sometimes forced policymakers and energy providers to revise their priorities. Shifting the site of intervention could have longterm consequences. When Japan's utilities abandoned household power cuts as the quick way to deal with supply shortages, they simultaneously paved the way for the new summer peak in consumption that would call for additional supply capacity to avoid disruption in the future. Consumption, in other words, was not just the result of supply: to an extent, it also shaped supply and supply shortages.

The GDR and Japan had their own distinct political regimes but they were by no means exceptional in having distinct national approaches to energy crisis. As Robert Lieber has stressed, Western Europe's response to the 1973 oil crisis was characterized by the absence of international coordination. Each country followed its own national self-interest and strategy. ${ }^{71}$ Indeed, Britain and Norway initially opposed joining the International Energy Agency, on the grounds that such an international body would threaten national sovereignty and limit their ability to deal with specific domestic issues. The energy shortages after the Second World War cast a long shadow. In the case of Britain, its fuel emergency policy was a direct child of the fuel shortages between 1946 and 1951. Like the GDR after 1953, post-war British governments tried not to interfere with domestic energy users directly. Unlike the GDR, the presence of strong trade unions also made it difficult to force night work on factory workers. Instead, the British government relied on electricity quotas for industry and moral appeals to domestic consumers. By leaving both working patterns and domestic consumption largely untouched, Britain's electricity system carried its two vulnerabilities into the 1960s and 1970s. In the winter of 1973-74, during the first oil crisis, it was trade union activity and domestic heating demand which caused the electricity crisis. Given how intertwined domestic policy and energy shortages have been in the twentieth century, it is not surprising that during the oil crisis in 1973, countries looked for solutions in national strategies rather than international coordination.

Discussions of moral economy have been dominated by food and food riots. ${ }^{72}$ Energy, like food, is a basic good on which human life and survival depend. There are

${ }^{71}$ Robert Lieber (1976), Oil and the Middle East War: Europe in the Energy Crisis, Cambridge, MA; Vessela Chakarova (2013), Oil Supply Crisis: Cooperation and Discord in the West, Lanham.

72 E. P. Thompson (1971), 'The Moral Economy of the English Crowd in the Eighteenth Century', Past and Present, 50: 76-136. Cf. Didier Fassin (2009), 'Les économies morales revisitées', Annales, 64 (6): 1237-1266; Frank Trentmann (2007), 'Before "Fair Trade": Empire, Free Trade, and the Moral Economies of Food in the Modern World', Environment and Planning D, 25 (6): 1079-1102. 
major differences, however, between what happens when the lights go out and what happens when the price of flour or bread goes through the roof. Energy shortages have rarely sparked the kind of riots and popular mobilizations that struggles over food have done. Only recently have there been sporadic protests against power cuts, such as the ones in Myanmar in 2007 and 2012. ${ }^{73}$ One reason for the relative absence of such protests is the potential for substituting one fuel for another - an ability that changes during the course of energy transitions. A second is displacement in political discourse and institutions. Energy shortages are usually framed in a different political register from famine. They are treated in terms of a welfare policy such as 'fuel poverty' or as a question of monopoly power and pricing. In this chapter, we have attempted to widen the terms of the debate regarding distributional fairness and power. Discussion of moral economy has favoured a view of society as a conflict between citizens/ consumers on the one hand and state/merchants on the other over the 'fair' price of food. But this is only one of several constellations. By integrating different users into the same system, modern energy networks made themselves vulnerable, at times of shortage, to additional conflicts: between different groups of consumers, between work and home, different energy-hungry activities, night and day and between different seasons. At a time when societies are debating the future of the grid, the history of energy shortages is a reminder that energy transitions involve moral and political as much as technological challenges.

\section{Acknowledgements}

We would like to thank the AHRC research grant (AH/K006088/1) and our colleagues of the 'Material Cultures of Energy' research project.

${ }^{73} \mathrm{http} / /$ www.aljazeera.com/news/asia-pacific/2012/05/20125235117172891.html (accessed 1 September 2017). 
